BOŽICA SLAVKOVIĆ, stipendista

Institut za savremenu istoriju

UDK 630(497.115)"1929/1941"

Beograd, Trg Nikole Pašića 11

\title{
ŠUME I ŠUMARSTVO NA KOSOVU I METOHIJI 1929-1941*
}

\begin{abstract}
APSTRAKT: Članak daje pregled $i$ ističe značaj šumskih kompleksa na prostoru Kosova i Metohije u periodu 1929-1941, rada državnih organa i banovinskih vlasti na unapređivanju šumarstva i rezultate rada sudova za ograničavanje državnih šuma. Rad je napisan na osnovu istraživanja u Arhivu Jugoslavije, Arhivu Srbije i odgovarajuće literature.
\end{abstract}

Ključne reči: Kosovo i Metohija, šume, šumarstvo, Sud za ograničavanje državnih šuma

Šume su u Srbiji oduvek imale veliki značaj jer je zemlja bila bogata šumskom vegetacijom. ${ }^{1}$ Raznovrsna klima, nejednak sastav tla kao i različita nadmorska visina doprineli su ne samo bogatstvu i raznovrsnosti šumskog pokrivača, nego i dobrom kvalitetu šumskog drveta. ${ }^{2}$ Šumski pojas u srednjem veku zauzimao je sve krajeve, sem korita reka i plodnih velikih ravnica, a u vreme Turaka šuma je bila uništavana bez zakonskih odredaba. Takva eksploatacija se nastavila i posle oslobođenja, a i davane su mnoge koncesije strancima. ${ }^{3} \mathrm{~S}$ obzirom na šumsko bogatstvo, država je morala da obrati pažnju na njihovo racionalno korišćenje, jer su se uglavnom sačuvale

* Rad je deo projekta Konflikti i krize: saradnja i razvoj u Srbiji i regionu u 19. i 20. veku (47030), koji finansira Ministarstvo prosvete, nauke i tehnološkog razvoja Republike Srbije.

${ }^{1}$ O učešću šumarstva u privredi videti: Jugoslavija 1918-1988, Beograd 1989; M. Jelić, R. Cvetković, Razvitak privrede između dva rata, Razvoj privrede FNRJ, Beograd 1956; M. Mirković, Ekonomska struktura Jugoslavije 1918-1941, Zagreb 1952; K. Mihailović, Privreda Jugoslavije 1920-1990, Jugoslavija 1918-1998, Beograd 1999; J. Lakatoš, Šumarstvo, Privredni almanah Jugoslovenskog Lloyda, Zagreb 1929; Šumarstvo i prerada drveta u Srbiji kroz vekove, zbornik, Beograd 1992; N. Vučo, Privredna istorija Jugoslavije, Beograd 1962. O šumarstvu po banovinama - šume prema vrsti uzgoja, po vrsti drveta, rezultati pošumljavanja, videti pregledno u Statističkom godišnjaku Kraljevine Jugoslavije 1-10 (1929-1940).

2 R. Perović, Kraljevina Jugoslavija - kratak pregled, Skoplje 1937, 23.

${ }^{3}$ S. Zečević, Siromaštvo Jugoslavije, Beograd 1936, 69. 
šume koje su se nalazile daleko od saobraćajnih linija. Pokrivale su 7.586.000 hektara površine Kraljevine SHS, što je bilo neprecizno određeno zbog nedostataka katastra, pa se smatralo da je taj broj bio i veći. ${ }^{4}$ Sredinom dvadesetih godina 20 . veka više od $23 \%$ teritorije tadašnje Južne Srbije bilo je pod šumama, da bi se desetak godina kasnije procenat povećao na 25,8 , odnosno šume su pokrivale površinu od 945.477 hektara tadašnje Vardarske banovine. $^{5}$

Šume Juga bile su „proizvod svih prirodnih sila koje vladaju u njemu i uticaja čoveka na njih“. ${ }^{6}$ Jovan Cvijić pominje da je u Metohiji „šumsko drveće izbijalo i raslo svuda po starim putevima, po ruševinama sela i starih crkava, a gotovo cela se oblast brzo pokrila žbunjem i šumom, negde gotovo neprohodnim". U manjoj se meri ista pojava desila i u nekim delovima Kosova. Cvijić ističe da je „čim bi koje parče zemlje bilo raščišćeno izbijalo žbunje i šibljike i naglo se razvijali“.7

Šumska vegetacija Južne Srbije bila je komplikovana, raznolika i bogata, pre svega hrastovom, bukovom, borovom, jelovom, smrečevom zajednicom. ${ }^{8}$ Ove šume u najvećem delu svog prostranstva bile su određene prirodnim zakonima da budu šume lišćara (hrasta i bukve). Hrast je zauzimao gotovo sva zemljišta pod šumom do 1.000 m nadmorske visine, odnosno onaj najbliži naseljima, dok je iznad $1.000 \mathrm{~m}$ najrasprostranjenija bila bukva. ${ }^{9}$ Veći deo starih bukovih šuma bio je „prašumskog tipa sa minimalnim uticajem čoveka“, pa su kao takve predstavljale „naročitu naučnu i turističku vrednost" ${ }^{10} \mathrm{U}$ manjem delu i na većim nadmorskim visinama ove šume bile su šume četinara. Smanjena su bila prostranstva četinarskih šuma najčešće „pod udarom sekire“, a zadržala su se samo ona teško pristupačna i udaljena. ${ }^{11}$ Takođe, zbog šumske ispaše koja je bila neuređena $\mathrm{i}$ neumerena, šume su bile uništavane. Neuredne seče i stalna ispaša „unaka-

${ }^{4}$ O šumarstvu 1918-1928. pregled daje Milan Marinović u tekstu Naše šumarstvo, Jubilarni zbornik života i rada SHS 1918-1928, I, Beograd 1928-1929, 209-220; Lj. Marković, Šume i šumarstvo našeg juga, Skoplje 1931; Ž. Miletić, Opšti pogled na šumarstvo Moravske banovine, Zagreb 1932.

${ }^{5}$ Najveći deo Kosova i Metohije u vremenu 1929-1941. pripao je Vardarskoj, a ostatak Zetskoj i Moravskoj banovini. Spomenica dvadesetpetogodišnjice oslobođenja Južne Srbije 1912-1937, urednik Aleksa Jovanović, Skoplje 1940, 656; V. Jovanović, Vardarska banovina 1929-1941, Beograd 2011, 390-393.

${ }^{6}$ Spomenica, 647.

7 J. Cvijić, Balkansko poluostrvo i južnoslovenske zemlje. Osnovi antropogeografije, Beograd 1966, 32.

${ }^{8}$ Spomenica, 147.

${ }^{9}$ D. Petrović, Stanje šumarstva u Srbiji i Južnoj Srbiji i zadaci njegovog unapređenja, Privredni letopis Zadužbine Nikole Spasića, knj. 1, Beograd 1936, 324.

${ }^{10}$ Spomenica, 649-650.

${ }^{11}$ Isto, 647. 
zile" su oblik i promenile sadržinu lisnatih šuma, i samo u onim predelima gde su naselja bila ređa šuma je zadržala deo svojih pozicija. Upravo iz tog razloga niske šume su bile najprisutnije u Južnoj Srbiji (tabela „Šume prema vrsti uzgoja“). Te šume su predstavljale „bolesnike koji životare i kojima treba brižljiva nega i duži odmor".

Šume prema vrsti uzgoja ${ }^{12}$

\begin{tabular}{|c|c|c|c|c|c|c|c|c|c|}
\hline \multirow{2}{*}{$\begin{array}{l}\text { Područje } \\
\text { sreza }\end{array}$} & \multirow{2}{*}{$\begin{array}{l}\text { Svega šuma } \\
\text { u hektarima }\end{array}$} & \multicolumn{2}{|c|}{ Visoke šume } & \multicolumn{2}{|c|}{ Srednje šume } & \multicolumn{2}{|c|}{ Niske šume } & \multicolumn{2}{|c|}{ Šikare } \\
\hline & & ha & $\%$ & ha & $\%$ & ha & $\%$ & ha & $\%$ \\
\hline Gnjilane & 53.042 & 4.500 & 8,5 & 2.000 & 3,8 & 30.042 & 56,7 & 16.500 & 31,0 \\
\hline Dragaš & 4.388 & 1.331 & 30,3 & & & 3.057 & 69,7 & & \\
\hline Kačanik & 14.232 & 3.887 & 27,3 & & & 10.150 & 71,3 & 195 & 1,4 \\
\hline Prizren & 21.058 & 2.243 & 10,6 & 1.181 & 5,6 & 9.715 & 46,1 & 7.919 & 37,7 \\
\hline Priština & 20.516 & 9.500 & 46,3 & & & 11.016 & 53,7 & & \\
\hline Uroševac & 23.645 & 11.424 & 48,3 & & & 12.221 & 51,7 & & \\
\hline Đakovica & 34.421 & 10.746 & 31,2 & & & 16.839 & 48,9 & 6.836 & 19,9 \\
\hline Istok & 24.813 & 9.504 & 38,3 & & & 9.675 & 39,0 & 5.634 & 22,7 \\
\hline K. Mitrovica & 24.741 & 10.119 & 40,9 & & & 10.318 & 41,7 & 4.304 & 17,4 \\
\hline Orahovac & 29.930 & 850 & 2,8 & & & 26.170 & 87,5 & 2.910 & 9,7 \\
\hline Peć & 33.376 & 17.983 & 53,9 & & & 8.181 & 24,5 & 7.212 & 21,6 \\
\hline Srbica & 18.028 & 5.468 & 30,3 & & & 9.115 & 50,6 & 3.445 & 19,1 \\
\hline Vučitrn & 19.582 & 2.209 & 11,3 & 6.569 & 33,5 & 7.785 & 39,8 & 3.019 & 15,4 \\
\hline Podujevo & 22.930 & & & 11.086 & 48,3 & 4.768 & 20,8 & 7.076 & 30,9 \\
\hline
\end{tabular}

\section{Šumski kompleksi}

U Arhivu Jugoslavije, $u$ fondu Ministarstva šuma i rudnika, može se naći referat „Šume i šumska privreda u Južnoj Srbiji“ Komisije za proučavanje šuma i šumskih prilika. Ovaj referat daje veoma temeljan opis površina i pošumljenosti srezova Južne Srbije, vegetacije, klime, predela koje obuhvataju, pitanja ograničenosti državnih šuma. Izdvojićemo samo šumske komplekse na Kosovu i Metohiji sa bitnim podacima da bismo stekli uvid u to koliki je značaj šuma bio na ovom prostoru.

Vučitrnski srez je imao površinu od 46.443 ha, dok su šume činile 19.266 ha (41,5\% teritorije). Kopaonik i njegovi ogranci, "prodirali“ su sa severa „silazeći“ do Kosova polja. Na jugozapadnoj strani sreza bila je planina Čičevica. Između ovih planina nalazilo se Kosovo polje, koje je uglavnom bilo upotrebljeno za ziraćenje. Šume su bile dobro pristupačne i do njih se moglo doći volovskim kolima. ${ }^{13}$

12 Statistika šuma i šumske privrede za 1938. godinu, Beograd: Ministarstvo šuma i rudnika, 1940, 46-50.

${ }^{13}$ Arhiv Jugoslavije (dalje: AJ), Fond Ministarstva šuma i rudnika (dalje: 68), 6825-110, Opis šuma Južne Srbije po vrsti i količini urađen od strane Komisije za proučavanje, avgust 1931, 351-358. 
Drenički srez se prostirao na 49.652 ha, dok su šume obuhvatale 23.564 ha $(57.5 \%)$. Srez je bio ispunjen brdima srednje visine, a najveća planina se nalazila na severnom delu sreza, visine oko 1.100 metara, a ka jugoistoku, odnosno Metohiji, visina brda je opadala. Najvećim delom bila je hrastova, pa bukova šuma. ${ }^{14}$

Nerodimski srez je imao površinu 58.175 ha, a površina šume iznosila je 29.481 ha (50.6 \%). Zahvatao je jedan deo Kosova, koji je činio severni deo sreza. Južni deo je bio ispunjen Šar planinom, Žar planinom, Jezeračko-Nerodimskim planinama i Crnoljevskim planinama. Ovo su sve bili delovi velikog planinskog masiva koji se prostirao od Koraba preko Šare. Te planine činile su oko gornjeg dela reke Lepenca župu Sirinić, a visoke su preko $2.000 \mathrm{~m}$. Na severoistočnoj strani bila je planina Žegovac, srednje visine. Planine su bile pristupačne i prohodne. Najviše je bilo bukove šume na Šar planini, pa onda hrastove. ${ }^{15}$

Gnjilanski srez je obuhvatao površinu od 157.425 ha, a šume su činile 90.327 ha $(57,4 \%)$. Srez je uglavnom bio planinski i brdovit po konfiguraciji zemljišta. U jugoistočnom delu ispunjavali su ga ogranci Skopske Crne Gore i njena zapadna strana, a u zapadnom delu sreza nalazili su se Žegovac i Koznica. Sa severa „prodiru rebra“ planinskog lanca kojim je išla srpsko-turska granica. Ravnica je činila prostor od Gnjilana uz Moravu do Kosova. Planine su bile srednje visine, do $1.300 \mathrm{~m}$. Šume su delom bile prostrane, jednostavne, a delom presecane naseljima. Prohodnost sreza je uglavnom bila dobra. ${ }^{16}$

Gračanički srez je imao 83.237 ha, a površina šume iznosila je 30.912 ha $(37,1 \%)$. Ovaj srez je zauzimao najveći deo Kosova polja. Ta površina je bila zauzeta za ziraćenje i nije imala gotovo nikakve šume. Šuma je bila po planinama oko Kosova polja, dakle na Lipovici, Drenici, Žegovcu i ograncima onog planinskog venca kojim je išla stara turska granica. Te planine su osrednjih visina do $1.200 \mathrm{~m}$. Srez je bio lako prohodan. ${ }^{17}$

Lapski srez je bio površine 58.943 ha, sa šumama na 40.053 ha (68\%). Sav je bio planinski i brdski, Kopaonik i njegovi ogranci bili su sa severne strane, spuštali su se na Kosovo, a zatim je išla „brdovita masa“ od Prištine na severoistok sve do stare srpske granice. Kopaonik je dostizao visinu preko $1.700 \mathrm{~m}$. Ostale su planine bile srednjih visina. U ovom srezu bilo je i dosta ravnica - Malo Kosovo oko reke Laba i varošice Podujeva i Veliko Kosovo u južnom delu sreza. Ta su zemljišta bila uglavnom oziraćena. Sve ove planine su bile prilično lako pristupačne i prohodne. ${ }^{18}$

\footnotetext{
${ }^{14}$ Isto, 358-360.

${ }^{15}$ Isto, 361-374.

${ }^{16}$ Isto, 318-336.

${ }^{17}$ Isto, 336-343.

${ }^{18}$ Isto, 344-401.
} 
Gorski srez je bio pravi planinski srez sa visokim planinama, a to su Šar planina, Korab i Koritnik. Mnogobrojni visovi imali su preko $2.000 \mathrm{~m}$, a neki su se peli i do $2.500 \mathrm{~m}$ (u Vraci). Koritnik je bio siromašan vodom za razliku od Šare i Koraba. Srez je bio prvenstveno suvatski, pa je zbog toga bio stočarski. Šume je bilo malo kao i ziratne zemlje. Transport je bio težak, jer su putevi uglavnom bili konjski. Srez je bio siromašan, stanovništvo je odlazilo većim delom u pečalbu. Površina sreza bila je 43.728 ha, šume je bilo svega 3.216 ha, odnosno $7.1 \%{ }^{19}$

Šarplaninski srez imao je površinu 71.997 ha, a u srezu je bilo svega šume 30.840 ha (42,8 \%). Srez je uglavnom bio u planinskom delu. U njemu se nalaze Šar planina i njeni ogranci, Koritnik na levoj strani Belog Drima i Paštrik sa ograncima na desnoj strani Belog Drima. To su visoke planine do 2.000 i preko $2.000 \mathrm{~m}$. Ravnice je bilo oko Prizrena u pravcu Suve Reke, Orahovca i Đakovice. Srez je bio dobro prohodan samo u ravnom delu. Planinski deo je bio upućen na konjski saobraćaj, što je za prenos šumskih proizvoda značilo veliku otežicu. Planinski deo sreza bio je siromašan, a naročito nekadašnji Haski srez, tj. podgorje Paštrika. ${ }^{20}$

Podgorski srez je obuhvatao 33.043 ha, šume 16.539 ha, a pošumljenost je bila $50 \%$. Ovaj srez je uglavnom bio planinski i brdovit. Ravnog zemljišta je između Mušutišta i Suve Reke. Inače je srez bio ispunjen Žarom i planinom Crnoljevom i njihovim ograncima. Žara je visoka planina sa visinama po $2.000 \mathrm{~m}$, dok je Crnoljeva srednje visine. Žara planina je bila teže pristupačna od Crnoljeve, kuda je prolazio drum Uroševac-Prizren. ${ }^{21}$

Podrimski srez je obuhvatao 79.264 ha, sa 31.824 ha šume, odnosno $40,6 \%$, rasute po celom srezu. Veći šumski kompleks postojao je u severozapadnom delu sreza oko sela Prčeva, dok su goleti bile između Belog Drima i varošice Orahovca. Planine su prelazile jedva 1.000 metara. $^{22}$

Đakovački srez se prostirao na 68.494 ha, a u njemu je bilo šume 37.718 ha $(55,1 \%)$. Ravničarski deo sreza uglavnom je ispunjavala hrastova šuma, planinski deo četinari i bukva, a tek u najnižim delovima su bili hrast i pitomi kesten. Planinski deo imao je visinu preko $2.600 \mathrm{~m}$, „vanredno lepog izgleda“. Iznad šume nalazili su se prostrani suvati i pašnjaci, dok su šume bile teško pristupačne. ${ }^{23}$

Pećki srez je zahvatao 74.634 ha, dok su šume činile 39.055 ha $(51,8$ $\%)$. Istočni deo sreza nalazio se u Metohiji i tu je uglavnom bila rasprostranjena hrastova sitna šuma. Zapadni deo bio je planinski sa visokim planina-

\footnotetext{
${ }^{19}$ Isto, 401-405.

20 Isto, 405-424.

21 Isto, 424-429.

22 Isto, 430-439.

23 Isto, 439-456.
} 
ma. To je predeo „vanredne lepote“. Imao je mnogobrojnih vrhova preko $2.000 \mathrm{~m}$, a pojedini su dostizali visinu i 2.500 metara. To su ogromne planinske mase sa strmim stranama. Najveće visine zauzimali su suvati i pašnjaci, a ispod su se nalazile šume. Sneg se dugo održavao tokom zime, pa je preko cele godine bilo tekuće vode. Planinski deo je bio prohodan samo na konjima. Ove šume bile su od prilične vrednosti, naročito kada je kroz Metohiju proradila železnica, kao i jadranska pruga kroz Pećku Bistricu i Čakor. Takođe, značajne su bile i velike površine suvata, koji su mogli da posluže za razvijanje racionalnog stočarstva u ovom kraju. ${ }^{24}$

Istočki srez se prostirao na 48.058 ha, dok je površina šume bila $29.045(60,4 \%)$. Srez je delom bio ravničarski, a delom planinski. Ispunjavali su ga delovi velikog planinskog masiva Žljeb - Mokra planina. To su visoke planine sa preko 2.000 metara, koje se iz ravnice "dižu“ dosta naglo i strmo, obrazujući u gornjem delu visoravan, na kojoj je bilo suvata i pašnjaka. Sav ostali deo sreza bio je deo Metohije i delom ravan, delom pod brdima i kosama. Ovaj drugi deo je bio lako pristupačan i prohodan, dok je prvi deo bio prohodan samo na konjima. ${ }^{25}$

Mitrovački srez je obuhvatao 66.321 ha, dok su šume činile 39.203 ha $(59,1 \%)$. Uglavnom je bio brdovit i planinski srez, koga su ispunjavali ogranci Kopaonika, Rogozne i Mokre planine. Ravnice je bilo samo oko Mitrovice i ka Metohiji. Visovi pojedinih planina išli su i do 1.700 metara. Prohodnost sreza u planinskom delu bila je slaba. ${ }^{26}$

Kačanički srez je imao površinu 29.137 ha, sa svega 15.572 ha šume $(53,4 \%)$. Srez su ispunjavali ogranci Skopske Crne Gore i Šar planine. Te dve planine grade Kačaničku klisuru kroz koju protiče reka Lepenac. U pogledu saobraćaja, šume u ovom srezu bile su dosta povoljne, jer su sve "padale" na železničku prugu koja je išla dolinom Lepenca. ${ }^{27}$

\section{Ograničavanje državnih šuma}

„Misija“ države bila je da u svojim šumama ima rezerve krupnog drvnog materijala koji „služi opštim interesima“ i čini državu sposobnom „za opstanak, odbranu i napredak“. Vlasnička podela šuma na ovim prostorima sprovedena je relativno kasno, tako da je najveći deo dugo pripadao državi. Na osnovu Zakona o ograničavanju šuma u Srbiji, Južnoj Srbiji i Crnoj Gori iz 1930, onaj ko u roku od godinu dana nije ubaštinio svoju šumu, smatralo se da se odrekao svojih prava u korist države. Ministarstvo

\footnotetext{
${ }^{24}$ Isto, 456-474.

25 Isto, 474-482.

${ }^{26}$ Isto, 482-492.

${ }^{27}$ Isto, 312-316.
} 
šuma i rudnika je 1936. ustupilo selima i pojedincima 7.266 ha državnih šuma, pašnjaka, livada i oranica. ${ }^{28}$ Tri četvrtine šuma u Južnoj Srbiji bile su u nedržavnim rukama i to najveći deo kao komunalno vlasništvo. Privatna svojina je najviše bila u obliku malih parcela, za razliku od državnih šuma, koje su bile na velikim kompleksima, mada im površina nije bila velika i to su mahom bili središni delovi planina ili brda. ${ }^{29}$ Obično se pri ograničavanju šuma gledalo da se bliži delovi ostave selima i opštinama za njihovu upotrebu. ${ }^{30}$

$\mathrm{Na}$ osnovu Zakona o ograničavanju državnih šuma osnovani su Sudovi za ograničavanje državnih šuma (dalje: SODŠ). Trebalo je blagovremeno obezbediti kredit za rad ovih sudova, koji su imali svoje članove i pravilnik. Jedan sud je trebalo da dobija 37.980-40.320 dinara mesečno. Rad sudova je trajao do završetka poslova, odnosno 5-6 meseci. ${ }^{31}$ Sud je trebalo da vodi računa o „gospodarskim, privrednim i zdravstvenim pogodbenostima" za život stanovnika na podnožju i ograncima šume, kao i o tome da je trebalo da granice šume budu što preglednije i vidnije, a cela šuma odnosno objekat da dobiju što pravilniji oblik radi lakšeg održavanja nadzora, pošumljenja i iskorišćavanja. Posle povlačenja privremene granične linije, sud je morao to da saopšti državnom zastupniku i ostalim zainteresovanim naročitim proglasom preko nadležne opštinske vlasti, koja je bila dužna da izda i saopšti proglas svojim građanima. Građani su imali pravo žalbe odmah po proglasu u određenom roku, ako su polagali pravo svojine na bilo koji deo ograničenog kompleksa. Sud nije imao dovoljno mesta za smeštaj osoblja i pogodne uslove, naročito za izradu skica, graničnih protokola i ostalih sudskih poslova, već je radio u teskobnim i dovoljno neosvetljenim sobama po seoskim kućama, pošto su šatori bili mali i nedovoljni za kancelariju, pa je to činilo smetnju za brz i pravilan rad. ${ }^{32}$ Komisija za proučavanje šuma je trebalo da ne opisuje granice pojedinih kompleksa već da iste ucrta u sekcije „đeneralštabnih karata“, pošto bi se po njima sudovi za ograničavanje bolje orijentisali nego po opisu granica, jer je lokalnih naziva za ista mesta bilo više, pa bi sudove bez skica mogli meštani u radu dovoditi u zabunu. ${ }^{33}$

Na prostoru Kosova i Metohije bila su osnovana tri suda - SODŠ za komplekse Paštrik, Koritnik, Borski Čestak, Beret i za Šar planinu, čiju je isplatu trebalo da vrši Šumska uprava u Prizrenu, SODŠ za komplekse

${ }^{28}$ V. Jovanović, n. d., 390-393; Spomenica, 654.

${ }^{29}$ D. Petrović, n. d., 323.

${ }^{30}$ Isto, 323; M. Savić, Naša industrija, zanati i poljoprivreda, IX knjiga, Sarajevo 1930, 36.

${ }^{31}$ Arhiv Srbije (AS), Fond Sudova za ograničavanje državnih šuma (SODŠ), fascikla V-a, Kosovska Mitrovica - administrativna akta 1933-1934, 25. mart 1933.

${ }^{32}$ AS, SODŠ, XXV, Priština - administrativna akta 1932-1935, Sud za ograničavanje državnih šuma Ministarstvu šuma i rudnika Beograd, 8. novembar 1933.

${ }^{33}$ Isto, Izveštaj informativne komisije o šumskim kompleksima koje treba ograničiti u srezovima Gračaničkom, Labskom, Vučitrnskom i Mitrovačkom, 15. avgust 1931. 
Lipovica, Roga Dramid, Romanište, Roga But, Grmija, Kačikol i dr. na teritoriji Šumske uprave u Prištini i Kosovskoj Mitrovici čiju je isplatu trebalo da vrši Šumska uprava u Prištini, SODŠ za komplekse Murgaš, Turjak, Mokra i Suva planina, Koprivnik, Dreničke i Juničke planine u srezu Beranskom, Pećkom, Istočkom i Đakovičkom, čiju je isplatu trebalo da vrši Šumska uprava u Beranu.

SODŠ za kompleks „Čičavica“ u srezovima Vučitrnskom, Dreničkom, Štavičkom i Kosovsko-mitrovačkom povukao je u maju 1933. privremenu graničnu liniju prema uputstvu Ministarstva šuma i rudnika. ${ }^{34}$ SODŠ za kompleks „Ogranak Kopaonika“ privremenu graničnu liniju povukao je u atarima opštine Slatinske, sreza Kosovske Mitrovice, Šaljske opštine, sreza Vučitrnskog, Dvorničke opštine, sreza Lapskog, opštine Lukovske, sreza Lapskog i Kosaoničkog i opštine Blaževske, sreza Kopaoničkog. Utrošio je ukupno 224.940 dinara na obavljene poslove. Sud je vodio računa o potrebama okolnih sela i želji Ministarstva da bi onemogućio stvaranje sporova, mada je bilo dosta prijava, koje su opet bile rešene u korist države. ${ }^{35}$ Građani sela Radiševa žalili su se na sudske granice jer im je premeravanjem bio sužen krug ispaše, pa su morali da smanje bavljenje stočarstvom, od čega su inače živeli. Zbog čestih sporova i nezadovoljstva naroda zajedno sa komisijom išla je i žandarmerijska patrola, po jedan policijski činovnik sa dva žandarma radi održavanja reda i čuvanja lične bezbednosti sudskog osoblja. ${ }^{36}$

U maju 1933. bio je konstituisan SODŠ za komplekse Paštrik, Koritnik, Borski Čestak (Vranište i Orćuša, Dragaška opština, i Globočica, Kruševačka opština), Đeret i $\mathrm{dr}^{37}$ Sud je radio do novembra, teren je bio veoma težak i zahtevao je naročito proučavanje. Zastupnici opština i kmetovi sela pružili su podršku i saradnju u poslu ograničavanja. U početku je stanovništvo sela Glubočice ograničavalo rad suda, a posle je i ono sarađivalo. Ipak je odatle bilo 18 prijava zbog livada, a Sud je priznao njihova prava svojine. Od jula do avgusta ograničen je državni kompleks Paštrika, a u avgustu je ograničen kompleks Koritnika dužine 13,55 km ne računajući albansku granicu u atarima opština Dragaške (Veliki i Mali Krstac, Gornja i Donja Rapča), Lopušničke (Buča i Brezna) i Žurske (Žur i Vrbnica). Pri radu u žurskoj opštini, sud je imao problema, jer je ,jedno lice sa brda pod jakim uglom odronjavalo veliko kamenje u pravcu suda". ${ }^{38} \mathrm{U}$ u oktobru 1933. sud

${ }^{34}$ AS, SODŠ, fascikla V a, Kosovska Mitrovica - administrativna akta 1933-1934, 18. maj 1933.

${ }^{35}$ Isto, 30. april 1933. Iz Slatinske opštine 58, Šaljske 2, Krpomajske 2, Dvoriške 38, Lukovske 40 prijava, iz Čičavskog kompleksa 4 prijave.

${ }^{36}$ Isto.

${ }^{37}$ AS, SODŠ, fascikla XXI, Administrativna akta za okrug Prizrenski 1933, 25. maj 1933.

${ }^{38}$ Isto, 23. april 1933. 
je trebalo da ograniči i suvat Šištevačkih planina u Gorskom srezu, duž albanske granice (ukupno 637 ha, od kojih je 1928. godine 362 ha ograničeno za državu, a kao neograničeno ostalo je 275 ha). Suvat je bio dobrog kvaliteta i mogao je da primi oko 800 grla stoke, ali se tuda u širini od $500 \mathrm{~m}$ protezao granični pojas srpskih vojnih vlasti, tako da bi se mogao koristiti samo onaj koji bi otpao od graničnog kompleksa (oko 75 ha). Okolna sela imala su dovoljno suvata za svoje potrebe, s obzirom na ne mnogo razvijeno stočarstvo u ovim krajevima. Sud je predlagao da se ovaj suvat ne ograničava jer bi država imala veće poreze nego prihode. Stanovnici sela Šištevca (srpski žitelji) kod diplomatskih vlasti pokrenuli su pitanje korišćenja suvata po pravilu koje daje konvencija o iskorišćavanju dvovlasničkih imanja, ali su prepreku činile albanske granične vlasti. ${ }^{39}$

SODŠ za komplekse Kosovskih šuma i Kopaonika ograničio je u julu 1932. privremenom graničnom linijom državnu šumu na kompleksu zvanom Grmija, Bukva, Lutovac, Velika Čuka i Krpi u ataru Devet Jugovića, sreza Gračaničkog. Bilo je dosta sporova i prijava, koje nisu bile rešene. ${ }^{40} \mathrm{U}$ avgustu je SODŠ izdvojio i obeležio privremeno graničnu liniju državne šume kompleksa Lipovica u ataru opštine Goleške, Lipljanske i Gornjo Dreničke, sreza Gračaničkog. Opština Lipljanska je podnela prijavu, a bile su još dve prijave sopstvenika. ${ }^{41}$ Obeležen je i kompleks Dzaru, Ramanište, Roga Dramit i Roga But u ataru opštine Devet Jugovića. Utrošeno je bilo ukupno na lične i materijalne izdatke 56.722 dinara. Ovaj kompleks je bio većinom obradiva zemlja a ne planinsko šumsko zemljište. Sud je, 1933. godine, ograničio komplekse Šator - Suvi Bunar - Duboku i Stolove - Zlaš - Kalaj - Ahmedov Rit - Mečja glava - Limanović u atarima opštine Kolićske, srez Lapski, opštine Bostanske, srez Gnjilanski i opštine Gračaničke, srez Gračaničke. Opština Prištinska imala je pravo svojine na šumu Grmija, $\mathrm{u}$ ataru sela Sofalije, jer je bila u njenoj neprekidnoj državnini preko 36 godina i tvrdila je da je ovu šumu „branila, štitila i čuvala i iskorišćavala nesmetano za potrebe svojih građana drvarenjem i uzimanjem vode koja je iz šume sprovedena u varoš“. Grmiju je osporavao i jedan od begova prištinskih, Ali Daniš beg, a prijavu je podnela njegova udovica preko svog zastupnika. Prijava je smatrana nedokazanom, jer nije bilo utvrđeno da su podnosioci bili naslednici pokojnog Ali Daniš bega, a podneti izvod iz arhivskog protokola bio je sačinjen na turskom jeziku i izdat od strane turske države. Izjave svedoka bile su sumnjive, jer su svedoci bili čifčije bega. Iz Budući da

${ }^{39}$ Isto, oktobar 1933.

${ }^{40}$ Laplje Selo i Čaglavica podneli su prijavu za oko 200 ha šume. Postojalo je još 49 prijava sopstvenika, ali nisu bile rešene. Za kompleks Grmija bilo je 40 prijava sopstvenika koje su bile rešene.

${ }^{41}$ AS, SODŠ, XXV, Priština - administrativna akta 1932-1935, avgust 1932. 
je ovaj deo bio važan u pitanju snabdevanja vodom varoši Prištine trebalo je sve učiniti da on ostane državna svojina, čak i ako bi spor dobio beg. Presudom od 11. avgusta 1933. sud je priznao pravo svojine opštini Prištinskoj dok je sve ostale odbio kao nedokazane. Apelacioni sud u Skoplju, međutim, poništio je ovu presudu, konstatovao da država Jugoslavija nema pravo svojine na spornu šumu Grmiju već da ovde postoji privatno pravo svojine i uputio na redovan građanski spor. ${ }^{42}$

Postojao je problem i sa šumom Araškaut („Srpska njiva“), jer je ona bila pod čiflukom, a 1916. godine kupio ju je brat nekadašnjeg vlasnika. Šuma je, međutim, bila „od vajkada“ u ataru sela Vesekovca. Navodni vlasnik je podneo „lažnu javnu ispravu“ o savesnoj državini, svojini i postojanju tapije za sporno zemljište. Pretpostavljalo se i da je imao lažne „profesionalne" svedoke. Takođe, podneo je prijavu za porez tek onda kada je saznao da Sud dolazi u njegovu opštinu da ograničava državne šume, odnosno 1934. godine. Interesantno je bilo da on 1929. godine nije prijavio 80 hektara šume koliko je posle tvrdio da ima, nego samo jedan hektar. Razlog zbog koga su članovi Suda smatrali da on potražuje ovu šumu, bio je u tome da je želeo da je proda rudniku Trepče. Država je posle rata markirala bukovu goru i prodavala je strugari koja se nalazila do same šume, što se smatralo dokazom da je država držala ovu šumu. ${ }^{43}$

U Lešničkoj šumi je selima u opštini Podujevskoj ostavljena utrina sa ponešto šume šikare. Seljani, koji su većinom bili Arnauti, hteli su da između sebe podele ono što bi ostalo izvan granice državne šume, isključujući pri tome državne doseljenike, bez obzira na to što se seoska utrina i šuma nije mogla deliti bez odobrenja nadzorne vlasti. Neki starosedeoci su odmah posle rata prodali svoja imanja naseljenicima i susedima i otišli u Tursku, ali su se uskoro i vratili, pa su zbog nedostatka novca samovlasno zauzeli seoske utrine kao i one delove koje je država s obzirom na konfiguraciju zemljišta i postojeći zakon o šumama čuvala kao svoje. Ovakve naseljenike je bilo teško oterati, jer su bili bez svake ekonomske mogućnosti. Država je smatrala da je neophodno da ima jednu šumu pored Malog Kosova, jer bi „sa njom korisno delovala po materijalni razvitak naselja na Kosovu“. Tu je bilo oko 60 sporova na 500 hektara, koji nisu imali tapije već samo posedovne prijave. ${ }^{44}$

U Prištini je juna 1935. konstituisan SODŠ za komplekse Bukoglav i dr. To su bila planinska sela razbijenog tipa, pa im se granična linija nalazi-

${ }^{42}$ Isto, 11. avgust 1933.

${ }^{43}$ Isto, Državni zastupnik Sudu za ograničavanje državnih šuma za komplekse Lešničke šume i dr., 28. novembar 1934.

${ }^{44}$ Isto, Izvadak iz izveštaja informativne komisije za srezove Gračaničke i Lapske, 18. maj 1934. 
la blizu kuća. Što se tiče kompleksa Suvi Bunar - Šator - Duboka - Stolove, bilo je 21 prijava privatnih lica. Mnoge prijave su bile neuredne jer u posedovnom listu i uverenju poreske uprave nisu bili izloženi poreski objekti na koje je prijavilac plaćao porez niti je bilo označeno od kada je plaćao porez na parcele na koje je navodno polagao pravo. Mnogima su njihovi navodi da se šuma nalazi u njihovoj svojini bili netačni, jer se iz uverenja šumske uprave videlo da se spornom šumom upravljalo kao sa državnom šumom i da je istu čuvala Šumska uprava u Prištini. Svedoci su bili većinom iz istih mesta odakle i prijavilac, pa im se stoga što su bili sunarodnici (Arnauti), nije moglo verovati, a i mnogi su vodili spor sa državom. Posedovni listovi su im bili iz 1929. tako da oni nisu mogli da budu dokaz i za ranije vreme. ${ }^{45}$

U Gnjilanskom srezu komisija je posle obilaska i pregledanja svih prostranijih šumskih zemljišta utvrdila da su se naselja u ravnijim i plodnijim krajevima nalazila u grupisanijim selima, a da su u planinskim i manje ili više brdovitim krajevima sela bila raštrkana u vidu mahala ili pojedinačnih kuća. Tako su šumski objekti bili razbijeni i prošarani naseljima i ziratnim zemljištem, da je ograničavanje većih objekata od 500 hektara i više bilo gotovo nemoguće. Ministarstvo šuma i rudnika nije bilo zaduženo ni na kakvo zemljište porezom ali su mnoge opštine označile velike površine kao neplodne, mada je najveći deo zemljišta građanstvo trajno iskorišćavalo. Gotovo ceo Gnjilanski srez bio je naseljen arnautskim življem, pa su sudovi smatrali da je trebalo kada se agrarne vlasti „budu ozbiljnije pozabavile“ naseljavanjem tog prostora zauzeti za kolonizaciju mnogo veće površine nego što je bilo zauzeto. Narod ovog kraja je bio vrlo siromašnog stanja i zadužen kod banaka i privatnih lica u Gnjilanu, a bavio se pretežno stočarstvom i voćarstvom, koje nije bilo dovoljno razvijeno. Komisija je predlagala katastarski premer Gnjilanskog sreza jer je smatrala da bi to bilo od velike koristi za saniranje privrednih i šumarskih pitanja ovog kraja jer je dosta zemljišta bilo upisano kao neplodno, odnosno prijavljeno kao manja površina. ${ }^{46}$ Sličan problem postojao je i pri ograničavanju kompleksa Dreničke planine jer je bio razbijenog tipa, pa je komisija predlagala da se oni delovi na koje ne polažu pravo sela i privatnici ostanu kao opštinska svojina. ${ }^{47}$

${ }^{45}$ Isto, jun 1935.

${ }^{46}$ Isto, Izveštaj i predlog informativne komisije za ograničavanje državnih šuma u srezu Gnjilanskom, 19. avgust 1931.

${ }^{47}$ Isto, Izveštaj informativne komisije o šumskim kompleksima koje treba ograničiti u srezovima Gračaničkom, Labskom, Vučitrnskom i Mitrovačkom, 15. avgust 1931. 
Šume prema vrsti vlasništva 1938. godine ${ }^{48}$

\begin{tabular}{|c|c|c|c|c|c|c|c|c|c|}
\hline & & & & & Nedržav & he povr & šine ( $u$ hekt & (rima) & \\
\hline & dručje & $\begin{array}{c}\text { Ukupna } \\
\text { šumska } \\
\text { površina (u } \\
\text { hektarima) }\end{array}$ & $\begin{array}{c}\text { Državna } \\
\text { površina }(u \\
\text { hektarima) }\end{array}$ & 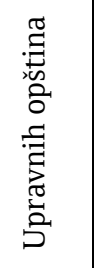 & $\begin{array}{l}\ddot{y} \\
\frac{\tilde{D}}{0} \\
\stackrel{d}{\Delta}\end{array}$ & 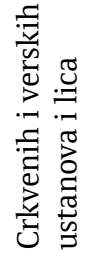 & 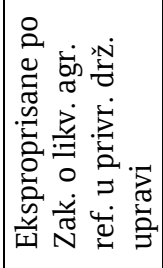 & 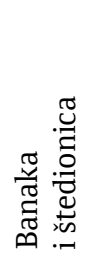 & 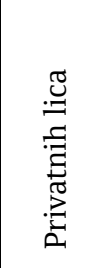 \\
\hline $\mathrm{Gnj}$ & ane & 53.042 & 7.126 & & 39.905 & 261 & & & 5.750 \\
\hline Dra & & 4.960 & 1.385 & & 3.420 & & & & 155 \\
\hline $\mathrm{Kac}$ & & 18.144 & 3.489 & 1.971 & 10.536 & 4 & & & 2.144 \\
\hline Pri & & 32.326 & 10.706 & 25 & 15.899 & 5 & & & 5.691 \\
\hline Pri & & 20.516 & 7.014 & 5.307 & 6.341 & & & & 1.854 \\
\hline Urc & evac & 23.645 & 8.600 & & 11.587 & & & & 3.458 \\
\hline Đal & vica & 38.591 & 9.824 & & 3.387 & 198 & 18.951 & 934 & 5.297 \\
\hline Istc & & 28.926 & 6.204 & & 9.225 & 50 & 5.383 & & 8.064 \\
\hline K. & trovica & 30.892 & 8.725 & 6.156 & 14.344 & 35 & 843 & & 5.789 \\
\hline Ora & ovac & 34.505 & 8.637 & 240 & 10.196 & & 11.261 & & 4.171 \\
\hline & srez & 37.031 & 11.842 & & 7.419 & 702 & 2.225 & 594 & 14.249 \\
\hline$P E$ & grad & 858 & 475 & & & 271 & & & 50 \\
\hline Srb & & 19.044 & 618 & & 8.177 & 90 & & & 10.159 \\
\hline $\mathrm{Vu}$ & & 21.832 & 5.316 & 910 & 14.246 & & & & 1.860 \\
\hline Poc & jevo & 28.921 & 9.700 & 4.050 & 10.312 & & & & 4.859 \\
\hline
\end{tabular}

\section{Unapređivanje šumarstva}

Početkom 1919. nastale su Okružne šumske uprave u sastavu Inspektorata šuma u Skoplju, a inspektorat je 1922. podignut na stepen Direkcije šuma. Direkcija je imala 18 šumskih uprava, čija su sedišta na Kosovu i Metohiji bila u Prištini, Kosovskoj Mitrovici, Prizrenu, ${ }^{49}$ Peći, Uroševcu i Istoku. Direkcija je imala zadatak da vrši nadzor nad šumama, sređuje iskorišćavanje šumskih proizvoda u nedržavnim šumama, brine se o pošumljavanju goleti i da unapređuje šumsku privredu. ${ }^{50}$

Na planskom uređenju državnih šuma radilo se forsirano po desetogodišnjem programu, a posle toga je trebalo urediti nedržavne šume. Prema Finansijskom zakonu od 1928/29. odobreno je bilo zaključenje zajma kod

${ }^{48}$ Statistika šuma i šumske privrede za 1938. godinu, 21-31.

${ }^{49}$ Prema podacima iz arhivskih izvora u Prizrenu je još 1912. postojalo Šumsko nadleštvo koje se zvalo „Orman Dairesi“, odnosno Šumska uprava, na čelu sa svršenim đakom turske ruždije - građanske škole. - AJ, 68-64-229, Šumska uprava Prizren, 6. april 1931. 
Državne hipotekarne banke na 20 miliona za unapređenje šumarstva u Južnoj Srbiji. ${ }^{51} \mathrm{Na}$ osnovu ovog trebalo je odrediti nekoliko komisija koje bi ispitale i proučile teren, šume i šumske prilike da bi se na taj način izradio generalni plan za rad na unapređenju u Južnoj Srbiji. Ta komisija je trebalo da pripremi knjigu „Šume i šumska privreda u Južnoj Srbiji“ (o kojoj smo govorili ranije u tekstu) i da umnoži šumske karte. Komisija za proučavanje šuma i šumskih prilika radila je tri godine i terenski i kancelarijski. Posao je završen zahvaljujući „velikom požrtvovanju i radu osoblja“, koje je radilo "prekovremeno i vredno". ${ }^{52}$

Stanje nedržavnih šuma bilo je više nego slabo. Nastojanja Banske uprave Vardarske banovine da zavede red u čuvanju ovih šuma na bazi da svaki vlasnik čuva svoju šumu, nisu dala pozitivne rezultate. Najlošije su se čuvale komunalne šume, dok je kod privatnih stanje bilo malo bolje. Čuvari u komunalnim šumama bili su veoma malo plaćeni. Državna vlast koja je trebalo da vrši nadzor i tako štiti šumu, suviše je bila slaba i na mnogim mestima uopšte nije ni postojala. ${ }^{53}$ Iz ovih razloga je Banska uprava 1935. zavela sistem zajedničkog čuvanja šuma pod naročitim javnim nadzorom i postavila 137 zadružnih čuvara šuma, koju su plaćali sopstvenici udruženih šuma. Efektivno postavljanje novih čuvara usledilo je u martu 1936, jer brdska sela nisu mogla da „saniraju“ šume bez osetne pomoći države i banovine. ${ }^{54}$ I pored teških terenskih prilika i ukorenjenog mentaliteta naroda, da je šumom trebalo slobodno raspolagati, državne šume su se čuvale dobro, ali kako je čuvar šuma trebalo da uzme učešća i u sprovođenju šumsko-uzgojnih mera bilo je potrebno povećati broj terenskog čuvarskog kadra. ${ }^{5}$

\section{Šumarski nadzor ${ }^{56}$}

Banske uprave

\begin{tabular}{|l|r|r|c|}
\hline \multirow{2}{*}{$\begin{array}{c}\text { Sresko načelstvo } \\
\text { Banske uprave }\end{array}$} & \multicolumn{2}{|c|}{ Površina u hektarima } & $\begin{array}{c}\text { Uposleno šumar- } \\
\text { sko osoblje }\end{array}$ \\
\cline { 2 - 4 } & \multicolumn{1}{|c|}{ Područja } & \multicolumn{1}{c|}{ Šumska } & \\
\hline Gnjilane & 170.600 & 53.042 & 3 \\
\hline Prizren & 167.800 & 49.174 & 2 \\
\hline Uroševac & 156.750 & 44.161 & 3 \\
\hline K. Mitrovica & 207.400 & 86.280 & 2 \\
\hline Peć & 288.890 & 139.911 & 3 \\
\hline Vučitrn & 60.750 & 21.832 & 1 \\
\hline
\end{tabular}

${ }^{51}$ AJ, 68-64-229, 31. januar 1929.

${ }^{52}$ Isto, 13. avgust 1931.

${ }^{53}$ D. Petrović, n.d., 330.

${ }^{54}$ Spomenica, 655.

${ }^{55}$ Isto, 656.

${ }^{56}$ Statistika šuma i šumske privrede za 1938. godinu, 96-105. 
Državna šumska uprava

\begin{tabular}{|c|c|c|c|c|}
\hline \multirow[b]{2}{*}{ Sedište Šumske uprave } & \multicolumn{2}{|c|}{ Čuvarski rejoni } & \multirow[b]{2}{*}{$\begin{array}{l}\text { Uposleno šumar- } \\
\text { sko osoblje }\end{array}$} & \multirow[b]{2}{*}{$\begin{array}{l}\text { Uposleno dru- } \\
\text { go osoblje }\end{array}$} \\
\hline & broj & $\begin{array}{c}\text { Površina od-do } \\
\text { u ha }\end{array}$ & & \\
\hline Prizren & 11 & $1.000-13.000$ & 13 & 4 \\
\hline Priština & 17 & $670-2.600$ & 22 & 2 \\
\hline K. Mitrovica & 13 & $500-2.300$ & 15 & 2 \\
\hline Peć & 13 & $1.300-5.500$ & 17 & 2 \\
\hline
\end{tabular}

Za unapređivanje šumarstva državna vlast je trebalo da obrati pažnju na suvate. Suvati, visoki planinski pašnjaci u Južnoj Srbiji, predstavljali su važnu privrednu granu u privredi ovog kraja. Stoka se u velikom broju puštala na ispašu na suvatima i planinskim pašnjacima. Bili su korisni i za izvoznu trgovinu, naročito za grčka, turska pa čak i američka tržišta gde se plasirao južnosrbijanski kačkavalj kao najbolji balkanski proizvod te vrste. Ovom pitanju, međutim, nije bilo posvećeno dovoljno pažnje. Direkcija je predložila da se u predlog budžeta za 1929-30. unese suma od 150.000 dinara za premeravanje i proučavanje suvata. Bilo je bitno rešiti ovo pitanje jer su se stočarima na grčkoj pijaci koja je „absorbirala“ svu sitnu stoku namenjenu za izvoz iz Južne Srbije, pojavljivali ozbiljni konkurenti iz Bugarske, naročito iz Trakijske oblasti, zatim iz Rusije, pa najzad iz severne Afrike (Alžir i Tunis). Direkcija je potencirala da bi se rešenjem suvatskog pitanja pomoglo najviše sitnom planinskom čoveku, pa ne bi dolazilo do njihovog iseljavanja i depopulacije. Državne suvate je trebalo izdavati pod određenim uslovima, prvenstveno okolnim zemljoradnicima čiji su se atari graničili sa ovim suvatima. Posle podmirivanja potreba planinsko-stočarskih sela, uzele bi se u obzir potrebe mešovitih sela kod kojih je zemljoradnja bila rentabilna i glavna privredna grana. Seoski atari koji se uopšte nisu dodirivali sa planinom na kojoj su se nalazili suvati isključivali su se od prava dobijanja suvata. Nakon njih, trebalo je podmiriti profesionalne stočare, i na kraju trgovce, stočarske trgovce, kasape i razne druge koji su uzimali ovce od zemljoradnika. Na ovaj način, trebalo je da jača svest o udruživanju ovih zemljoradnika u zadruge. Svi stočari koji su napasali stoku na državnim suvatima, imali su plaćati taksu i postojala su pravila za isplatu. Policijske vlasti su preduzimale mere predostrožnosti iz razloga javne bezbednosti, a Direkcija je tražila i da se pojača brojno stanje žandarma kako bi se svaki suvat mogao iskoristiti do svog maksimuma u interesu državne kase. ${ }^{57}$ U godinama pre 1929, državni suvati su izdavani pod višegodišnji zakup licitacijom a više puta i „ispod ruke“ trgovcima koji nisu

${ }^{57}$ AJ, 68-64-229, Direkcija šuma-Skoplje, 18. januar 1929. 
imali veze sa stočarstvom, što je imalo za posledicu eksploatisanje stočara koji su bili primorani da plaćaju zakupcima višestruke takse od zakupnih. Suvati su se prostirali u Južnoj Srbiji na površini oko 200.000 ha, a do 1929. na državne suvate pušteno je do 230.000 stoke, većinom ovaca. $\mathrm{Na}$ ime takse plaćeno je 1926. godine 2.100.000, a 1927. - 1.800 .000 dinara, zbog sniženja taksi, na traženje i pod uticajem narodnih poslanika. $\mathrm{Na}$ osnovu prakse došlo se do zaključka da je način izdavanja popaše na suvatima putem „nagonice“ tj. slobodnom prijavom sopstvenika uz plaćanje propisane takse bio mnogo pravedniji i odgovarao uglavnom potrebama stočarstva nego pomenuti način izdavanja većih prostora suvata špekulantima pod višegodišnji zakup. ${ }^{58}$ U maju 1929. upućeno je ministru Lazaru Radivojeviću pismo da izađe stočarima u susret zbog oskudice stočne hrane usled duge zime i da taksu za popašu na državnim suvatima ukine ili smanji. Stočari iz Prizrena i okolnih sela, a naročito Gorskog sreza, žalili su se da ne mogu podneti visoku taksu, a i „da su državne suvate zakupljivali nekoliko stočarskih trgovaca koji nisu bili stočari već su kupovali stoku i hranili je na državnim suvatima i prodavali po Grčkoj i Turskoj, pa su im pod teškim uslovima ustupali ove državne suvate i sa velikom zakupninom" ${ }^{59}$ Direkcija je odgovorila da taksa "nije visoka već vrlo jeftina“, takođe da je ministar bio „pogrešno obavešten“, jer je vođeno računa da se prvo ispašom zadovolje stočari zemljoradnici po spiskovima sudova opština, ali često se dešavalo da su se među članovima sudova nalazili oni koji su želeli da se obogate na račun građana. Direkcija je sumnjala da se nisu baš oni žalili ministru „ne za račun siromašnog naroda već na svoj“. Bilo je odlučeno da se smanji taksa na polovinu za ona lica koja su se za suvate obratila po spisku opštinskih sudova, a čiji ukupan broj stoke nije prelazio 50 komada. ${ }^{60}$

Savez agrarnih zajednica Skoplje se u januaru 1930. obratio ministru šuma i rudnika, objašnjavajući mu „koliko je stočarstvo važna privredna grana u Južnoj Srbiji, i da je stoga trebalo obratiti pažnju na takse, način izdavanja suvata i da nema razloga da se stočari sumnjiče za rad protiv države". ${ }^{61}$

Na državnim suvatima se od 1934. radilo na njihovom planskom uređenju na osnovu desetogodišnjeg plana za uređenje. Kaptaža vode, izgradnja cisterni, lokvi i pojila, uništavanje štetnog korova, poboljšanje flore, izgradnja gospodarskih zgrada za preradu mleka, pastirskih skloništa, puteva i turističkih kućica na izvanredno lepim, mirisnim i prostranim

\footnotetext{
${ }^{58}$ Isto, Generalna direkcija šuma Beograd - Direkciji šuma u Skoplju, 8. mart 1929.

${ }^{59}$ Isto, Ministar poljoprivrede - ministru šuma i rudnika, 18. maj 1929.

${ }^{60}$ Isto, Direkcija šuma Skoplje - Ministarstvu šuma i rudnika Beograd, 27. maj 1929.

${ }^{61}$ Isto, Savez agrarnih zajednica Skoplje - ministru šuma i rudnika, 18. januar
} 1930. 
suvatima Juga, trebalo je da budu elementi koji bi suvate učinili „osetno korisnim narodu i državi“ ${ }^{62}$

Državna svest o koristi goleti dovela je do uspostavljanja mera za njihovo pošumljavanje, što je takođe unapređivalo šumarstvo u Južnoj Srbiji. Mišljenje da su goleti nekorisne i štetne koje je ovladalo u intelektualnim krugovima delom je preneto i na ostale slojeve naroda, pa je država morala da radi i na podizanju svesti o potrebi i korisnosti pošumljavanja, odnosno da radi na promeni mentaliteta. Propaganda je trebalo da se dobro organizuje i da se, osim šumara, i narod upozna sa koristima šume. U školama, na javnim predavanjima i preko propagandne literature, učinilo bi se mnogo na „razvijanju ljubavi naroda prema šumi“ ${ }^{63} \mathrm{Za}$ pošumljavanje goleti bila je neophodna stručna i materijalna saradnja države i banovine, kao i radni doprinos vlasnika zemljišta. Trebalo je „forsirano izvršiti izdvajanje goleti, izraditi program njihovog pošumljavanja, obezbediti potrebne sume $u$ budžetima, a narodu stavljati na raspoloženje potrebne sadnice besplatno, kao i stručno rukovodstvo državnih i banovinskih organa". Šuma sa svojom rentabilnošću od $2 \%$ trebalo je da zauzme one goleti na kojima nije bilo ispaše za stoku kao i one koje nisu bile sposobne za poljsku kulturu. Sistem oglednih pošumljavanja koja su izvedena 1930/31. zamenio je stručne neuspehe uspehom, a dalji ogledi Banske uprave su pojačali stručnu stranu radova i omogućili jevtiniji način uspešnog pošumljavanja. Šumarstvo Juga je usredsredilo pažnju na širenje i sistematizaciju narodnog pošumljavanja dajući besplatne sadnice u dovoljnom broju, kao i stručna uputstva. ${ }^{64}$

Na teritoriji Šumske uprave Peć prema izveštaju komisije nije bilo šuma i goleti, koje je trebalo veštački pošumljavati. Kod ove uprave je održavan šumski rasadnik u svrhe popularizovanja i propagande šumarstva, ali krediti za isti nisu redovno otvarani za svaku godinu, pa je usled prekidanja kontinuiteta i svaka tačna ili približna evidencija bila izgubljena utoliko pre što je stručno osoblje često menjano. Rasadnik je osnovan 1922. godine na površini od 30 ari. Stavljeno je pod zabranu oko 2.500 ha devastiranih šuma i šumskog zemljišta u ataru sela opštine Rugovske u Pećkom srezu, radi podmlađivanja biljaka i drveća i pošumljavanja prirodnim načinom državne svojine. Ovo zemljište je bilo delom pod šikarom, delom požarima očišćene površine, a delom neracionalnim sečom devastirane šume. ${ }^{65}$ Šumska uprava u Prizrenu napravila je pregled o pošumljavanju goleti na svojoj teritoriji, na mestu zvanom Cvilen, što je bilo neograničeno zemljište. Na ovom prostoru najraspostranjeniji su bili bagrem i hrast, ali nisu nam poznati rezul-

\footnotetext{
${ }^{62}$ Spomenica, 658. O pošumljavanju piše i D. Petrović, n. d., 341-343.

${ }^{63}$ D. Petrović, n. d., 348.

${ }^{64}$ Spomenica, 663; M. Savić, $n$. d., 37-38.

${ }^{65}$ AJ, 68-64-229, Šumska uprava Peć, 1. april 1930.
} 
tati pošumljavanja. ${ }^{66}$ Državna i banovinska vlast su u periodu 1912-1937. potrošile oko 9 miliona dinara za proizvodnju sadnica i pošumljavanje Južne Srbije. ${ }^{67}$ Kada se, međutim, uzmu u obzir ogromni prostori goleti, kao i broj hektara isečene šume namenjene domaćoj potrošnji i izvozu i kako se mali broj odgajivao i održavao, onda se vidi da je na pošumljavanju „učinjeno tako malo, da to kao neki dokaz naše privredne šumske aktivnosti ne bi smeli isticati“. ${ }^{68}$

U nedržavnim šumama dinamičnost eksploatacije u svim vidovima dostigla je neželjene srazmere, za razliku od državnih šuma gde to nije bilo toliko istaknuto. Zemljoradnik se snabdevao iz svojih zabrana i seoskih šuma, osim ako u njima nije bilo ono što je njemu potrebno, pa je kupovao iz državnih šuma. Cene šumskih proizvoda iz državnih šuma za zemljoradnike bile su niske. I pored toga što je državna šumska uprava na Jugu prihvatila geslo „naša mušterija naš gazda“, ipak nisu mogli da eksploatišući državne šume u granicama njihovih moći rasterete nedržavne šume. Zbog toga je bilo bitno režimsko iskorišćavanje državnih šuma. Direkcija šuma je prešla na izradu ogreva u sopstvenoj režiji. Drvarske režije u Uroševcu i Kačaniku davali su zarade okolnom stanovništvu do 2.000 .000 dinara godišnje. ${ }^{69}$

Šumska privreda Južne Srbije svodila se na eksploataciju drva, i to pre svega zbog neodgovarajuće saobraćajne infrastrukture. Najviše su drvo koristili domaća radinost i zanati. Bukove i hrastove šume bile su prevashodno korišćene za izradu železničkih pragova, dok su velike količine drvenog uglja upotrebljavali za ogrev. Seljaci su tokom zime sekli šumu za ogrev, ne koristeći otpatke od drugih seča. ${ }^{70}$ Prema podacima o poslovanju šumskih uprava iz februara 1930. uočava se da je najviše šumskih taksi naplaćeno u mitrovačkom i prizrenskom povereništvu. ${ }^{71}$

Poslovanje okružnih šumskih uprava ${ }^{72}$

\begin{tabular}{|l|r|r|r|}
\hline $\begin{array}{c}\text { Okružna šumska } \\
\text { uprava }\end{array}$ & $\begin{array}{c}\text { Kubnih } \\
\text { metara drva }\end{array}$ & $\begin{array}{c}\text { Taksa za domaću } \\
\text { upotrebu (dinara) }\end{array}$ & $\begin{array}{c}\text { Taksa za špekulaciju } \\
\text { (dinara) }\end{array}$ \\
\hline K. Mitrovica & 8.487 & 136.700 & 178.525 \\
\hline Peć & 585 & 13.696 & 16.970 \\
\hline Priština & 483 & 5.800 & 8.520 \\
\hline Prizren & 5.164 & 65.309 & 83.357 \\
\hline
\end{tabular}

${ }^{66}$ Isto, Šumska uprava Prizren.

${ }^{67}$ V. Jovanović, n. d., 392.

${ }^{68} \mathrm{~S}$. Zečević, $n$. d., 72.

${ }^{69}$ Spomenica, 664-665.

${ }^{70}$ V. Jovanović, n. d., 393.

${ }^{71}$ AJ, 68-19-96, Rekapitulacija, 27. februar 1930; V. Jovanović, Prirodni resursi i njihova eksploatacija - primer Vardarske banovine, Arhiv, god. X, br. 1-2, Beograd 2009, 60-75.

${ }^{72}$ AJ, 68-19-96, Rekapitulacija, 27. februar 1930 (V. Jovanović, Vardarska banovina, 394). 
Iz upoređenja prihoda i rashoda u periodu 1924-1937. proizilazi da je Ministarstvo šuma i rudnika primilo 67,038.075.83 dinara prihoda iz državnih šuma Južne Srbije, a za isto vreme izdalo na upravu i unapređenje šuma Južne Srbije 84,272.881.18 dinara. Prema ovome, bilans je za državu bio pasivan. Razlozi za ovu pasivnost bili su u sniženim taksama za drvo i ispašu za zemljoradnike i stočare, $u$ troškovima za ograničavanje državnih šuma, za plansko uređenje šuma i suvata, za pošumljavanje goleti i uređenja bujica. ${ }^{73}$ Takođe, nije bilo dobro smišljenog i uređenog plana rada $\mathrm{u}$ šumskoj privredi. ${ }^{74}$ Zakon o šumama iz 1929. nije bio povoljan za razvoj šuma, jer je prema mišljenju Dragoljuba Petrovića, savetnika Odeljenja za šumarstvo Ministarstva šuma i rudnika, služba zadužena za šumarstvo bila „razdeljena“, a ne „po jednom shvatanju i načelu“. Nije bilo dovoljno potrebnih državnih organa, sreskih šumarskih referenata i čuvara šuma. ${ }^{75}$ Trebalo je dosta ozbiljnih radova u šumarstvu, da bi se doprinelo stabilnosti u državnom šumskom dobru i da bi se dostigli odgovarajući prihodi. ${ }^{76}$

\section{Božica Slavković}

THE FORESTS AND FORESTRY IN KOSOVO AND METOHIJA 1929-1941

\section{Summary}

The article provides detailed account about forests and forestry in Kosovo and Metohija 1929-1941. It focuses on the work of the state institutions to improve forestry, and also analyses the work of the courts for establishing the forest boundaries. Forest vegetation which was very diverse and rich, started to decline as the result of of intensive exploitation. The authorities started to increase the number of forest guards, and to work in public with intention to change the attitude towards the usage of the forests stressing the importance and benefits. The article presents the most important forest complexes which were on the territory of Kosovo and Metohija including their brief descriptions. It was written on the archival sources of the Archive Serbia and Archive of Yugoslavia.

\footnotetext{
${ }^{73}$ Spomenica, 668.

${ }^{74}$ D. Petrović, $n$. d., 331.

${ }^{75}$ Isto, 351-352.

${ }^{76}$ Spomenica, 668. O privrednom planu za razvoj šumarstva: M. Savić, n. d., 39-40.
} 